\title{
Development of junior students' emotional intelligence in terms of New Ukrainian School: realities and prospects
}

\author{
Svitlana Prakhova*, Natalya Makarenko, and Iryna Shumilina \\ Kryvyi Rih State Pedagogical University, Kryvyi Rih, 50086, Ukraine
}

\begin{abstract}
The article presents a theoretical overview of the phenomenon "emotional intelligence" (EQ). The perspectives of different foreign and domestic psychologists on the concept of EQ, its origin and structure are analised. The importance of studying emotional intelligence and the possible ways of its development as a priority of the New Ukrainian School (NUS) are emphasized. The basis of EQ study is determined as the interrelation of the concepts of "emotional - intellectual". Certain positive and negative characteristics of advanced emotional intelligence are highlighted. A methodological toolkit for EQ study is developed and presented. Some prospective ways of its development in ontogeny under appropriate conditions are substantiated. There is an algorithm elaborated for the complex consistent work on EQ development.
\end{abstract}

\section{Introduction}

Due to certain education reforms and the transition of classical domestic education onto the rails of the "New Ukrainian School", the issues related to diagnostics and developing strategies for the formation of "emotional intelligence" (EQ). EQ are gaining a new level of relevance. At the present stage of the educational process development, which attempts to function "in a new way", empirical studies are of particular importance, especially those devoted to comparing different aspects of the study of students' emotional intelligence in terms of "classical" and "New Ukrainian School" (NUS) and the search for the system of EQ development in the context of NUS.

It should be noted that among the psychic phenomena identified at the end of the twentieth century, it is difficult to find such a phenomenon that would attract more attention of scientists and representatives in practical (applied) fields of research than EQ. Almost every national scientific studies collection presents the results of research on this topic.

This topic is especially relevant in terms of NUS, one of the tasks of which is the development of communicative knowledge, abilities and skills of the child. It is also significant to investigate the problem of emotional intelligence and look for ways to develop it in a turbulent flow of information, in the presence of clipping type of thinking along with an excessive immersion into the virtual world.

The key formulas of NUS formulated in the concept of new content of education are: information and communication competence; civic and social competences. All the competencies in NUS possess a common feature: the ability to manage emotions; apply emotional intelligence. In this regard, it is necessary to define the peculiarities of the child's personal emotional states clearly; to account for new elements in the emotional sphere at different stages of ontogeny and to develop a step-by-step plan for the effective development of emotional intelligence.

\section{Objectives of the study}

Considering the relevance of the subject under study, the objectives of this article are to investigate the role of emotional intelligence of the individual, opportunities and factors of their development on the example of junior students studying in the realities of new Ukrainian school system and to compare their statistics data with the sample group of students who were junior students before 2018 .

\section{Methods}

The experimental study of junior students' emotional intelligence level was organized in two stages. The first one covers the period before the reform implementation (academic year 2017/2018), and the second stage was realised in the course of the changes related to the functioning of the NUS (academic year 2019/2020). The diagnostic sections were performed with the junior students in Year 2 in the middle of September of each academic year. In total, 110 students of Kryvyi Rih Scientific and Technical Metallurgical Lyceum № 16 participated in the study. According to the time terms of the diagnostics, all the students were divided into two groups. The first group included primary school students who became first graders by 2018 (the year of the beginning of NUS introduction), and the second group consisted of students who started

\footnotetext{
*Corresponding author: svetlankaprakhova@gmail.com
} 
their studies in September 2018, under the new curriculum.

Traditionally, there are two main approaches to measuring emotional intelligence: the questionnaire (aimed at using questionnaires that the researcher presents as self-report) and the test. Each of these approaches corresponds to a specific type of emotional intelligence model: ability/capability models as well as mixed (eclectic) models.

The first type of the models interprets emotional intelligence as a purely cognitive construct associated with the processing of emotional information. The second type - explains emotional intelligence as a set of cognitive, personal, motivational traits providing an effective understanding and management of emotions.

A complete description of the methodological toolkit is presented by S. Derevianko [8]. V. Zarytska provides a set of methods for diagnosing the level of self-control and self-regulation development [9].

In addition, the diagnostics with the help of the mentioned T-methods are supplemented by communication with the child (Q-methods), observations and expert assessments (L-methods). That is, there is currently present a really valid and reliable toolkit for determining the level of emotional intelligence development [11].

In the diagnostic part of our empirical study, we aimed to determine the general modality and frequency of manifestation of students' dominant emotions, with the latter determined by using the common psychodiagnostic method of K. Isard's Differential Emotions Scale (DES). The general level of junior students' emotional intelligence was determined by the results obtained through applying a modified version of the classic one of the complex method by M. Nguyen, which consists of two projective techniques: "Domestication: the world of things - the world of people - the world of emotions", "Three desires" and the methods "What - Why - How". Although in the classic version this diagnostic tool is aimed at studying the characteristics of preschool children, we decided to use its modified version with primary school students, most of whom are no more than six or seven years old.

\section{Results and discussions}

Realising that the concept of intellect by J. Piaget was of an extremely narrow character, G. Gardner was able to hypothesize about the multiplicity of manifestations of intelligence, among which are interpersonal and intrapersonal ones. G. Gardner believed that these types of intelligence were the key to self-cognition (cognitive insight), to understanding one's emotions and feelings, to managing one's behavior, to understand other people and interact with them effectively. Such characteristics are also inherent in emotional intelligence [6].

In the early twentieth century, E. Thorndike assumed the existence of social intelligence as the ability of a person to understand others in communication, to establish interpersonal relationships as well as to maintain friendly relations.
At the end of the last century, social intelligence was viewed as a component of emotional intelligence. The term "emotional intelligence" was coined by J. Mayer and P. Salovey [13]. The idea was then further developed in D. Goleman's book, the journalist and psychologist [5]. According to these scientists, emotional intelligence is a collection of cognitive abilities to identify, understand and manage emotions.

A global study of this phenomenon is presented in the writings of D. Goleman, who considers emotional intelligence as an ability to interpret one's own emotions and the emotions of others in order to use the information received and fulfill one's own goals. The significance of the issue is already covered in a subheading to his edition of "Emotional Intelligence: Why It Can Mean More Than IQ". According to the author, contrasting these concepts (EQ and IQ) in scientific research increasingly leads us to believe that "people with high intellectual abilities turn out to be staggeringly bad pilots of their own lives" [5].

The Israeli researcher-theorist on emotional intelligence R. Bar-On [3] developed his own concept of emotional coefficient to measure emotional and social competence, identifying five subcomponents characterizing the structure of EQ (self-understanding, communicative potential, anti-stress potential, etc.).

Summarizing the findings of the key founders of the study on the problem, we can identify five major components of emotional intelligence: a person's awareness of their own emotions; regulation of one's emotions based on self-awareness; the ability of a person to direct their emotions to achieve a specific goal of activity; empathy as the ability to understand other people's emotions; the ability to have a friendly relationship with others.

Quite a thorough study of the EQ phenomenon was also conducted by domestic scientists. Thus, a generalization of the theoretical foundations of the study of emotional intelligence (stages of forming the understanding of the EQ concept; the periods of formation and study of emotional intelligence; analysis of the features of studies of emotional intelligence concept content in the post-Soviet area) were presented by M. Savchuk [17].

E. Nosenko [14] sees EQ in the context of the unity of external and internal regarding the determination of the mental and considers that emotional intelligence as an aspect of revealing the inner world of the personality reflects a measure of reasonableness of the person's attitude to the world, to others and to themselves as the subject of life activities.

The Russian scientist D. Lusin proposed to interpret the concept of emotional intelligence as "the ability to understand their own and others' emotions and control them, i.e. cognitive ability" [12].

According to M. Shpak [19], emotional intelligence is an integrative personality trait, which is conditioned by the dynamic unity of affect and intelligence through the interaction of emotional, cognitive, connotative and motivational features and is aimed at understanding one's own emotions along with providing emotional experience management of emotional state, 
subordination of emotions to mind; it also promotes self-knowledge and self-realization through enrichment of emotional and social experience.

The influence of the level of emotional self-control and self-regulation development on the students' emotional intelligence development was investigated by V. Zaritskaya [9]. Presenting the results of the diagnostics, the author noted that the level of ability to self-control and self-regulation depends on the level of overall emotional excitability.

The influence of emotional intelligence peculiarities (emotional self-regulation, self-reflection, authenticity) of group members on group dynamics and individual dynamics of personality in the group is covered in V. Romanova's work [16]. It is proved that the general emotional participants positively influence the organization, responsibility and orientation of the group.

Emotional intelligence as the basis of communicative competence and the possibility of its development (with reference to the research of the French psychologist M. Kets de Vries) is presented by V. Fedorchuk [18].

It should be noted specifically that in the scientific literature the following synonymous with the concept of EQ terminology are presented as: "emotional reasoning" (E. Nosenko), "emotional self-awareness" (O. Vlasov), "emotional competence" (K. Saarny), "emotional thinking" (O. Tikhomirov), "emotional literacy" (K. Steiner), "emotional giftedness", "social intellect" (R. Ronald) to provide evidence of the emotional intelligence concept breadth and, in a certain way, define the ways of its development.

The priority area of modern research is the study of the problem of anxiety and frustration, their relationship with the level of students' emotional intelligence, the impact of models of learning in the NUS [15].

It is important, from our point of view, to carry out evaluation of the positive and negative properties of emotional intelligence. In particular, S. Boyko [4] explored emotional intelligence as a factor in resisting information stress. And according to the journalistpsychologist from Scientific America, Agata Blaszczak-Box, emotional intelligence has not only positive but also certain negative components. It contributes to increasing stress, makes us defenseless, it also makes us feel responsible for what we are unrelated to, and tempts us to manipulate others for personal gain. It was experimentally researched and featured in the September 2016 issue of Emotion. German psychologists Miriam Bechtoldt and Vanessa Schneider showed that students with high EQ level significantly increased their stress during the experiment. Therefore, it took more time to stabilize the emotional state of such subjects. The results obtained indicate the extreme vulnerability, perceptiveness of individuals with high levels of EQ. And in the context of the information society, this takes on new content and needs further and deeper study [2].

In the process of qualitative and quantitative analysis of the empirical data, the main focus was put on the comparative analysis of the peculiarities of junior students' emotional response to different-vector emotional situations.

As the results of K. Izard's Differential Emotions Scale (Fig. 1) show, the students of the first group (those who went to school before September 2018) turned out to bring such emotions as interest, surprise, fear, joy and shame at the top position of the rank distribution chart.

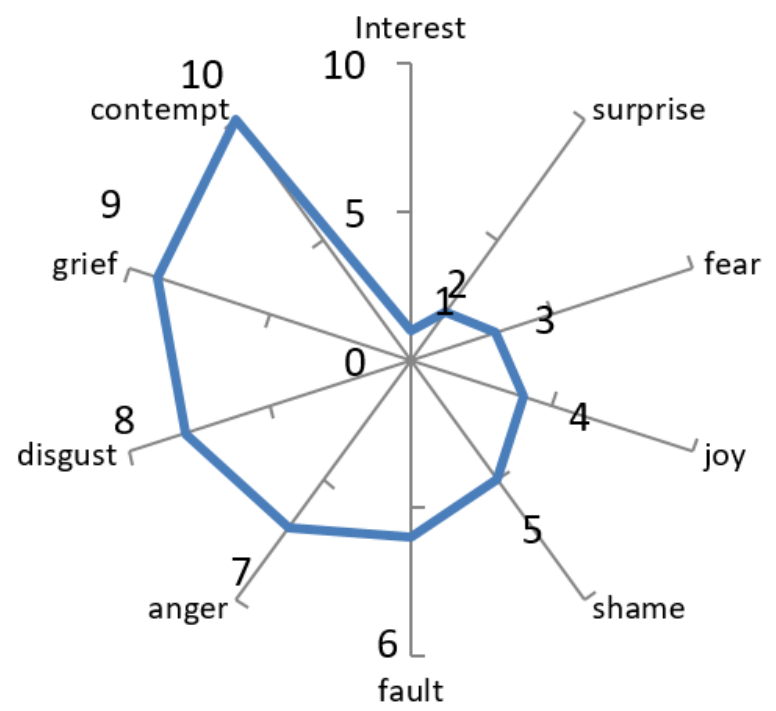

Fig. 1. The scale of differential emotions according to K. Izard's method ("classical" school students' diagnostic results)

At the same time, the results of the diagnostics of the junior students studying in the NUS system show that the positive emotions of interest and joy persist in the top five positions, with the difference that the students who went to school in September 2018, the joy moves from the fourth position in the rank of significance onto the first (Fig. 2).

The results of individual conversations with students in both groups revealed that the emotional experiences of students during this age period are primarily related to the learning process, interpersonal relationships with classmates and participation in various games and entertainment. Analyzing the curriculum of the new Ukrainian school and the variants of the programs that were developed for it, it can be stated that in previous years too little time was devoted to the students' emotional unloading in the course of their educational activity, which, in its turn, could not but affect the level of their emotional intelligence.

The statistics presented above are fundamentally important, since it is the junior school age that is sensually colored and characterized by a considerable emotional sensitivity that has an impact on the development of emotional intelligence. So, as the results of the first part of our empirical study show, the students of the NUS system are characterized by a more positive emotional coloring of the educational process. While negative emotional experiences almost 
did not change their rank positions, with the exception of the parameter "fear", which moved from the third to fifth position, which is significant in the context of the "fearless" attitude of the modern student to the learning process.

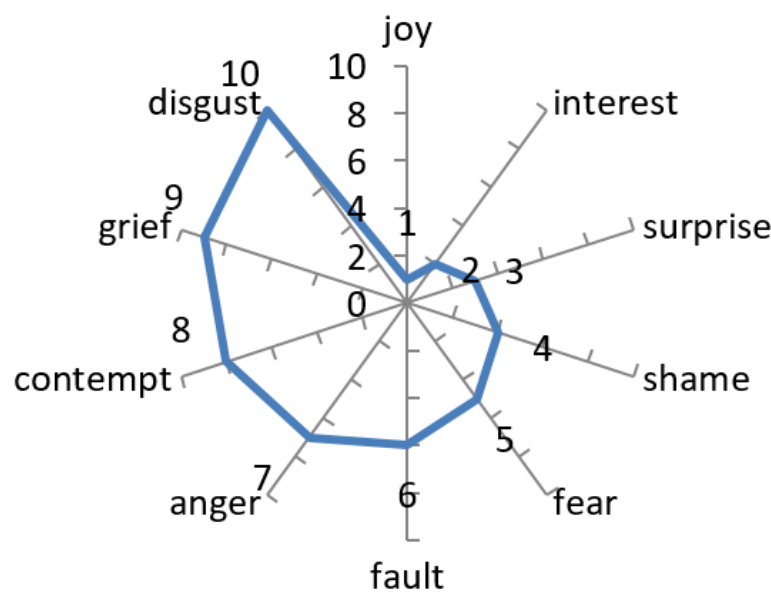

Fig. 2. The scale of differential emotions according to K. Izard's method (NUS school students' diagnostic results)

The quantitative and qualitative assessment of N. Nguyen's methods results showed the presence of differences in the levels of students' emotional intelligence of the first and second groups (Fig. 3). As the results of projective diagnostics showed, NUS students have significantly higher EQ parameters: high level $-20 \%$, medium level $-60 \%$, low level $-20 \%$.

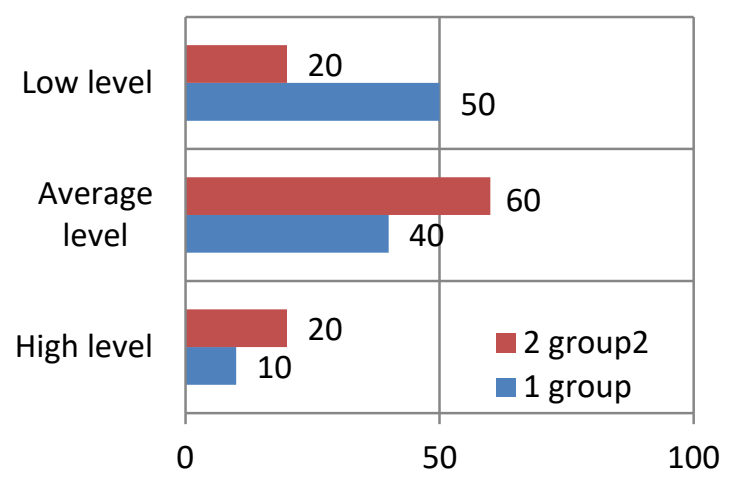

Fig. 3. Levels of junior students' emotional intelligence according to M. Nguyen's methods results

For comparison, students in the "classical" school had a parameter of $50 \%$ low level of emotional intelligence. This statistical correlation is the evidence that the new system of educational process in Ukraine contributes to the emotional unloading of students in a great way, which in its turn, creates the preconditions for the development of empathy related to interpersonal relationships among children.

In the new educational environment, the process of emotional intelligence and socialization is accelerating. Modern children are more likely to develop the ability to differentiate and classify emotional experiences and build their interpersonal relationships on this basis.
However, all this is possible only with the proper approaches to the system of students' emotional intelligence development at different stages of their maturation in the educational process.

There are several points of view regarding the possible ways of developing emotional intelligence. The founders of the concept J. Mayer and P. Salovey believe that it is impossible to raise the level of emotional intelligence, because it is a relatively stable characteristics of a man. D. Goleman is convinced that the development of emotional intelligence is possible at different stages of ontogeny, from childhood, with subsequent improvement in adulthood. R. Bar-On states that EQ develops over time, it can be improved with the help of trainings, exercises and therapy [7].

I. Andreeva [1] notes that the level of emotional intelligence of a child is related to a similar quality of the mother, but there is no connection with the parental characteristics. This fact refutes the "genetic" theory and works in favor of the "educational" one, since genes are inherited from their parents equally. But, on the other hand, there is a clear link between EQ and the dominance of the right or left brain hemisphere, which is a congenital feature. According to some studies, right-hemisphered people have much better emotional intelligence.

The researchers found another pattern: the higher the parental education level and financial position of the family is, the higher emotional intelligence of adolescents appears. However, in this situation, it is difficult to understand the cause and effect relation.

Thus, having analyzed the scientific literature on the problem, we are inclined to think about the possibilities of emotional intelligence development as a reality (and the experimental study of EQ in the context of NUS is therefore a testimony). This is possible through the introduction into the field of education of psychological and pedagogical technologies for the formation of emotional competence by K. Saarney (awareness of their own emotional states, the ability to recognize the emotions of others; the ability to overcome their negative experiences, etc.) and the scheme of emotions recognition, suggested by D. Lusin and N. Bylkin, according to which the eventual product of emotional intelligence is an ability to make decisions based on the reflection and comprehension of emotions, which represents a differential assessment of events with personal content.

The school activities should be systematic and cover not only students of NUS, but also parents and teachers. According to some scientists' survey [10] it is difficult for a teacher to determine what emotions a child has. Most often, teachers talk about personal characteristics (confidence-insecurity, kindness, modesty, mobility, etc.). Only $9 \%$ of those polled identified the emotional poles (positive-negative), but, unfortunately, could not identify their modality.

The emotional intelligence development realization will only be implemented by the algorithm:

\begin{tabular}{ccccc}
$\checkmark$ & to & \multicolumn{2}{c}{ familiarize } & participants of the \\
educational & process with & theoretical & knowledge
\end{tabular}


about the emotional sphere of personality (psychoeducation);

$\checkmark$ the development of methodological recommendations for systematic formation of emotional competence, emotional thinking, emotional memory, etc. with children, parents, teachers;

$\checkmark \quad$ the diagnostics of participants' EQ level in terms of educational process;

$\checkmark$ the study of existing disturbances in the emotional sphere (asynchronous disharmonious development, authentic reactive states, psychopathic behaviors, etc.);

$\checkmark$ the implementation of exercises, trainings, workshops on the development of emotional intelligence in the educational activities;

$\checkmark \quad$ the results evaluation and correction.

Consequently, this is completely in line with the concept of NUS. Prior to this period, modern school was focused mainly on the development of students' academic abilities, on the cognitive sphere of personality (formation of knowledge, skills and abilities), whereas the emotional development of students was not given due attention. There is an indisputable fact: one of the elements of the educational content is the formation of emotional-value attitude of a person to themselves, to other people, to the surrounding reality (I. Lerner). The consequences of emotional "illiteracy" are manifested in a significant increase of interpersonal conflicts, an increase in cases of depression, cruelty or violence. Therefore, considering I. Andreeva's claim, the development of emotional intelligence can be viewed as a factor enhancing the psychological culture of society as a whole.

It is undoubtful, when creating a consistent process on the emotional intelligence development, it should be born in mind that only interactive methods of activating knowledge about the problem, innovative technologies will not only enable the participants of the educational process, but also help to actually develop their EQ. Unfortunately, the school still has a traditional monologic (mentoring) form of influence on the child, which can only cause negation and rejection. However, the introduction of cognitive innovators' findings into school practice will make this process interesting, understandable as well as consciously necessary. For example, acquainting participants of educational process with modern researches in the style of recommendations like «How ... enhance ... develop ... improve ..." may finally lead to the Achiever Experiment. That is, after reading the book of recommendations how to regulate their own emotions (empathically listening, "reading" non-verbal signals, influencing another person, etc.), the student tries to put them into practice, evaluate the result and correct their mistakes. It is also necessary to use case-methods (with a detailed analysis of life situations) in the development of EQ. In our view, effective methods may be mental provocations, group work, volunteer activities, etc.

\section{Findings}

Thus, the junior students' emotional intelligence development is a part of the process of their socialization under the conditions of the NUS integrating. The empirical study results of the modality and levels of emotional intelligence of "classical" students and students enrolled in the NUS system reveals significant differences in the construction of cognitive-interpretative patterns of students' recognition of emotions and states. Apparently, the students of the NUS are more adaptable to the changing conditions of the educational process, they have a clear understanding of the objects and phenomena of the surrounding reality. Moreover, modern students quite easily interpret the complex emotions that arise in their familiar life circumstances.

However, despite the positive results of the experimental study of the level of students' emotional intelligence level in Year 2, it is worth noting that these are only the first steps in the educational realities of the New Ukrainian School. The issue of the current techniques and methods of students' EQ development at different stages of their adulthood still remains uncovered. This is where we see the prospects for further research in the field of emotional intelligence.

\section{References}

1. I. Andreeva, Emotsionalnyiy intellekt: issledovaniya fenomena. Voprosyi psihologii 3, 78-86 (2006)

2. A. Blaszczak-Box, Too Much Emotional Intelligence is a Bad Thing (2017), https:/www.scientificamerican.com/article/toomuch-emotional-intelligence-is-a-bad-thing/. Accessed 25 Oct 2019

3. R. Bar-On, Emotional Intelligence in Men and Women: Emotional Quotient Inventory: Technical Manual (Multi-Health Systems, Toronto, 1997)

4. S. Boiko, in Naukova dyskusiia: pytannia pedahohiky ta psykholohii: zbirnyk materialiv Mizhnarodnoi naukovo-praktychnoi konferentsii (Kyivska naukova orhanizatsiia pedahohiky ta psykholohii, Kyiv, 2017), pp. 125-128

5. D. Goleman, Emotional intelligence (New York: Bantam Books, 1995)

6. H. Gardner, Multiple intelligences: the theory in practice (Basic Books, New York, 1993)

7. D. Goleman, Emotsionalnyy intellekt. Pochemu on mozhet znachit bolshe chem IQ (Mani. Ivanov. Ferber, Moskva, 2013)

8. S.P. Derevianko, Metodychni zasoby diahnostyky emotsiinoho intelektu. Visnyk Chernihivskoho natsionalnoho pedahohichnoho universytetu. Seriia: Psykholohichni nauky 128, 95-99 (2015)

9. V. Zarytska, Vyvchennia rivnia rozvytku samokontroliu i samorehuliatsii emotsii yak elementiv emotsiinoho intelektu studentiv $u$ protsesi fakhovoi pidhotovky. Aktualni problemy psykholohii. Zbirnyk naukovykh prats Instytutu 
psykholohii im. H.S. Kostiuka 10(5), 141-146 (2010)

10. E.P. Ilin, Emotsii $i$ chuvstva (Piter, Saikt Petersburg, 2008),

11. A. Kozlova, Emotsiinyi intelekt (Shkilnyi svit, Kyiv, 2018)

12. D. Lyusin, Organizatsiya znaniy ob emotsiyakh: vnutrennyaya struktura kategorii "emotsii" (Razvitiye, Moskva, 1996)

13. J.D. Mayer, P. Salovey, The intelligence of emotional intelligence. Intelligence 17(4), 433442 (1993). doi:10.1016/0160-2896(93)90010-3

14. E. Nosenko, N. Kovryha, Emotsiinyi intelekt: kontseptualizatsiia fenomenu, osnovni funktsii (Vyshcha shkola, Kyiv, 2003)

15. S. Prahova, N. Makarenko, Napryamki prevenciyi shkilnoyi trivozhnosti molodshih shkolyariv: realiyi sogodennya ta perspektivi "novoyi ukrayinskoyi shkoli" (na prikladi longityudnogo doslidzhennya). Problemi suchasnoyi psihologiyi 44, 234-254 (2019)

16. V. Romanova, Doslidzhennia vplyvu emotsiinoho intelektu chleniv hrupy ta yikh osobystisnykh proiaviv na yavyshcha hrupovoi dynamiky. Aktualni problemy psykholohii. Zbirnyk naukovykh prats Instytutu psykholohii im. H.S. Kostiuka, 10(19), 468-477 (2015)

17. M.R. Savchuk, Teoretychni osnovy doslidzhennia emotsiinoho intelektu (Theoretical basis of the research of emotional intelligence). Efektyvna ekonomika 5 (2017), http://www.economy.nayka.com.ua/?op=1\&z=560 8. Accessed 28 Nov 2019

18. V. Fedorchuk, in Aktualni problemy psykholohii osobystosti ta mizhosobystisnykh vzaiemyn: materialy VII Mizhnarodnoi naukovo-praktychnoi konferentsii, Kamianets-Podilskyi-Kyiv-ZheshuvBrest, 2015, pp. 276-282

19. M. Shpak, Emotsiinyi intelekt v konteksti suchasnykh psykholohichnykh doslidzhen. Psykholohiia osobystosti 1, 282-288 (2011) 